De accouniant zal de inrichting van de boekhouding niet ondergeschikt mogen maken aan zijn contrôle-arbeid: het afleggen van rekening en verantwoording blijft het primaire doel van de boekhouding, maar waar een efficiente controle langs dezelfde weg mogelijk is, verdient combinatie van middelen, i.c. een op beide doeleinden gerichte indeeling van het rekeningschema, aanbeveling. Het "Normalkontenplan", hoewel. niet gebonden aan het middel van de doorschrijfboekhouding vindt daarin een zeer geschikt werktuig en is met zijn zorgvuldig doorgevoerde scheiding van Vermogensrekeningen en Vermogensmutatierekeningen, een niet te versmaden steun voor den accountant.

Doorschrijfboekhoudingen, waarin veelal dit uniforme rekeningschema wordt toegepast, verdienen meer waardeering van de zijde van de accountants dan, naar ik meen, tot nu toe het geval is.

Voorzoover de afkeerigheid bij de accountants een gevolg is van de grootere moeite verbonden aan de vastlegging van de gecontröleerde cijfers, heb ik getracht om aan te toonen, dat dit bezwaar niet steekhoudend is.

\title{
SOCIALE BEDRIJFSECONOMIE
}

In Economisch Statistische Berichten van 29 Augustus 1945 bepleit Prof. ten Doesschate onder den titel "Sociale Bedrijfseconomie" een wijziging in de bedrijfseconomische opvattingen met dien verstande, dat het gewenscht is .,het opperste doel van bedrijf en onderneming te zien in de voorziening der samenleving van zoo goed mogelijke producten of diensten, met opoffering van een zoo gering mogelijk quantum productiemiddelen". Hier wordt dus een gewijzigde formuleering gegeven van het economisch principe, welke economische grondwet volgens bestaande opvattingen aldus luidt: De mensch zal in zijn streven naar welvaart steeds trachten een zoo groot mogelijk resultaat te bereiken met een zoo klein mogelijk offer.

In een samenleving. waarin de economische verhoudingen zijn gebaseerd op ruilverkeer, zullen echter resultaat en offer beide slechts kunnen worden gemeten in geld. Op welke wijze zal de ondernemer, die b.v. voor het produceeren van een bepaald artikel, grondstoffen en halffabrikaten betrekt van een boven hem in de bedrijfskolom gelegen bedrijfstak, kunnen bepalen of hij inderdaad een zoo gering mogelijk kwantum productiemiddelen opoffert. Toch alleen door na te gaan, of de totale ,kostprijs" van zijn product zoo laag mogelijk is? Wanneer hij b.v. met een goedkoopere grondstof een. even bruikbaar product kan voortbrengen, dan zal dit uit sociaal oogpunt verkieslijk zijn. aangezien daarbij, naar kan worden aangenomen, minder productiemiddelen worden opgeofferd. Voor den betreffenden ondernemer komt dit echter alleen tot uitdrukking in een lager geldoffer. Wanneer aanwending van een goedkoopere grondstof, gepaard aan vermeerdering van den daaraan te besteden arbeid, uiteindelijk een besparing in geld oplevert, zal de ondernemer hiertae moeten overgaan. De maatschappelijke besparing komt voor hem alleen tot uitdrukking in een geldelijk voordeel voor zijn onderneming.

Het probleem is trouwens niet uitsluitend kwantitatief. Wanneer voor eenvoudige werkzaamheden gebruik gemaakt wordt van arbeiders, die beter gekwalificeerden arbeid kunnen leveren, kan niet worden gezegd

$\mathrm{m} \mathrm{a} \mathrm{b}$ blz. 71 
dat een grooter kwantum productiemiddelen dan noodig geofferd wordt. Zoowel echter sociaal gezien als van het standpunt van de onderneming. vindt hier verspilling plaats.

Ook het bereikte resultaat wordt in geld gemeten en zal onder normale omstandigheden - dus bij afwezigheid van een prijsvaststelling alleen op grond van de kostén - grooter zijn naarmate de aan de maatschappij bewezen dienst grooter is.

Zoolang de maatschappij de onderneming kent in haar huidigen vorm, dus zoolang het geldelijk voordeel uit het ondernemen genoten, ten bate komt van hen door wie, of namens wie de onderneming geleid wordt. kan niet anders verwacht worden dan dat het streven van de leiding blijft, dat voordeel zoo groot mogelijk te doen zijn. Zoolang blijven de bedrijfseconomische wetten gelden, welke voor die omstandigheden zijn afgeleid.

Het wordt thans vrij algemeen als de taak van de Overheid beschouwd regelen te stellen, welke eventueele nadeelige sociale gevolgen van dat winststreven teniet doen of beperken. De taak der ondernemers zal het zijn aan de nakoming van deze regelen loyaal mede te werken. Dat der gelijke regelen de bedrijfseconomische opvattingen, voorloopig op detailpunten, kunnen beïnloeden, is aan te nemen. Zoo kunnen b.v. maatregelen van overheids- of semi-overheidslichamen. op het terrein der credietverleening, de opvattingen omtrent de financiering van de onderneming beïnloeden. Het uitgangspunt der bedrijfseconomie echter, dat de ondernemer streeft naar een zoo groot mogelijk overschot van opbrengst boven offer, wordt hierdoor naar mijn meening niet aangetast.

Naast economische, kunnen voor den ondernemer zeer zeker ook andere, b.v. ethische maatstaven gelden. Deze kunnen hem leiden tot besluiten, welke in strijd zijn met hetgeen economisch rationeel is. Het kan echter m.i. geenszins tot den taak van de bedrijfseconomie worden gerekend haar opvattingen in verband hiermede te wijzigen. $Z_{i j}$ bestudeert het rationeele handelen van den ondernemer op grond van het economisch principe. Daarbij gaat zij er vanzelfsprekend van uit, dat fiscale en economische overheidsvoorschriften naar behooren worden nagekomen. Dit kan ook van den ondernemer worden geëischt.

Een vraag echter als deze: Moeten de nadeelige gevolgen van het winststreven der ondernemers worden ondervangen door het aanleggen van hoogere ethische maatstaven of door beperkende overheidsbepalingen, is in beginsel geen onderwerp der bedrijfseconomie, maar een vraagstuk der politiek.

Van een ,sociale bedrijfseconomie' kan dan ook m.i. geen sprake $z$ ijn. De sociale economie bestudeert de werking van het economisch principe, gezien uit een maatschappelijk standpunt, de bedrijfseconomie bestudeert deze werking binnen het kader van de bedrijfshuishouding. $Z_{i j}$ heeft daarbij de bestaande omstandigheden als uitgangspunt te nemen en zal zich bij wijziging der omstandigheden daaraan moeten aanpassen. Aan haar uitgangspunt verandert dit naar mijn meening echter niets.

\section{INGEKOMEN BOEKEN}

Mr. B. Moret, ,.De verhouding tusschen den public accountant en den internen controleur'. Openbare les bij de aanvaarding van het ambt van lector aan de Nederlandsche Economische Hoogeschool. Uitgave $H . J$. Paris Amsterdam 1946, prijs ing. $f$ 1.25.

m a b blz. 72 
Dr. M. J. H. Smeets en J. H. Meihuizen, „Beknopte Belastinggids” 7e druk. Uitgave L. J. van Veen Uitgeversmij. A'dam, prijs ing. $f 4.90$. gecart. $f 5.75$.

Dis. M. J. van der Ploeg. "De administratie als hulpmiddel bij het bedrijfsbeheer. Uitgave N. Samson N.V. Alphen a/d Rijn, prijs geb. f 5.25 .

Drs. S. C. Bakkenist en Drs. W. J. v. d. Woestijne, .De positie van het Fabrikanten-merkartikel in de Kruideniersbranche". Uitgave C. Misset Uitgeversmij. Doetinchem, prijs ing. f 5.-.

\section{SYSTEMATIEK VAN DE REPERTORIA}

\section{Van de Redactie}

$\mathrm{Nu}$ de Centrale Documentatiedienst inzake Bedrijfsorganisatie zich met de verzorging van de Repertoria heeft belast en deze dus weer regelmatig in ons tijdschrift zullen worden opgenomen, besloot de redactie een herdruk van de systematiek van de Repertoria op te nemen, teneinde den lezers het raadplegen en rangschikken van de verschillende excerpten gemakkelijker te maken.

\section{A. ACCOUNTANCY}

I. Algemeen

II. Het accountantsberoep

1. Algemeen

2. Geschiedenis en ontwikkeling

3. Opleiding, examen, scholing

4. Organisatie en wettelijke regeling van het beroep

III. Leer van de inrichting

1. Algemeen

2. Stelsels en methoden van boekhouding

3 Techniek van boekhouding. administratieve en mechanische hulpmiddelen

4. Interne controle

IV. Leer van de contröle

1. Algencen

2. Taak en verantwoordelijkheid van den accountant als controleur; de verklaring

3. Techniek van de algemeene contröle en van bijzondere onderzoekingen

4. Organisatie van den contrôle-arbeid

\section{B. BEDRIJESHUISHOUDKUNDE}

\section{a. ALGEMEENE BEDRIJFSHUISHOUDKUNDE}

I. Algemeen

II. Bedrijfshuishoudkunde als wetenschap

1. Algemeen

2. Doelstelling, werkmethode, verhouding tot andere wetenschappen

3. Geschicdenis

4. Onderwijs

III. Waarnemingsmiddelen

1. Algemeen

2. Statistiek en documentatie

3. Koopmansboekhouding

4. Kameralistiek

5. Economische voorlichting 